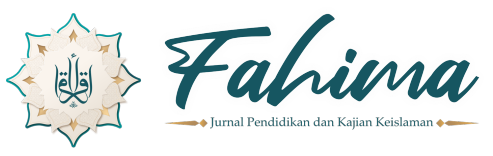

Fahima: Jurnal Pendidikan dan Kajian Keislaman

E-ISSN: 2808-4349 | P-ISSN: 2808-747X | Volume 1 No. 1 Januari 2022

\title{
PENGARUH PEMBELAJARAN JARAK JAUH DAN PERAN ORANG TUA TERHADAP PRESTASI BELAJAR PAI
}

\author{
Ikke Nurjanah $^{1 *}$, Abdullah Hadziq ${ }^{2}$
}

1 SMP Negeri 2 Kerjo Karanganyar, Indonesia

${ }^{2}$ Universitas Nahdlatul Ulama Surakarta, Indonesia

*Surel Penulis Koresponden: gendhizt22@gmail.com

\begin{tabular}{|l|l|l|l|}
\hline \multicolumn{4}{|c|}{ Riwayat Artikel: } \\
\hline Dikirim: 4-11-2021 & Ditinjau: 18-11-2021 & Diperbaiki: 2/1/2022 & Diterima: 3/1/2022 \\
\hline
\end{tabular}

\section{Abstrak}

Pembelajaran Jarak Jaub merupakan solusi terbaik yang dapat dilakukan dunia pendidikan saat ini untuk menghindari penyebaran virus COVID-19 beserta variannya. Dengan menerapkan pembelajaran jarak jauh, diharapkan siswa tidak hanya sekedar mendengarkan penjelasan materi dari guru, melainkan turut aktif dalam keiatakn pembelajaran berupa mencari sumber informasi dari media lainnya.

Penelitian ini bertujuan untuk mengetabui pengarub pembelajaran jarak jauh dan peran orang tua terhadap prestasi belajar PAI siswa kelas VIII SMP Negeri Mojogedang Kabupaten Karanganyar Tabun Pelajaran 2020/2021. Hipotesis yang diajukan adalab babwa pembelajaran jarak.jauh pembelajaran jarak jauh dan peran orang tua berpengaruh signifikan terhadap prestasi belajar PAI siswa kelas VIII SMP Negeri Mojogedang Kabupaten Karanganyar Tabun Pelajaran 2020/2021.

Jenis penelitian ini adalah deskriptif kuantitatif dengan metode pengumpulan data melalui angket, observasi, wawancara dan dokumentasi. Subjek, penelitian siswa kelas VIII SMP Negeri 2 Mojogedang dengan populasi 260, dan diambil sampel 116 siswa.

Hasil penelitian menunjuk.kan bahwa: pembelajaran jarak jaub berpengaruh positif dan signifikan terbadap Prestasi Belajar PAI siswa kelas VIII SMP Negeri 2 Mojogedang Karanganyar Tahun Pelajaran 2020/2021; peran orang tua berpengarub positif dan signifikan terhadap Prestasi Belajar PAI siswa kelas VIII SMP Negeri 2 Mojogedang Kabupaten Karanganyar Tabun Pelajaran 2020/2021; pembelajaran jarak jaub dan peran orang tua berpengaruh positif dan signifikan terhadap Prestasi Belajar PAI siswa kelas VIII SMP Negeri 2 Mojogedang Kabupaten Karanganyar Tabun Pelajaran 2020/2021.

Kata Kunci: pembelajaran jarak jauh, peran orang tua, prestasi belajar PAI 


\begin{abstract}
Distance Learning is the best solution that the world of education can do today to avoid spreading the COVID-19 virus and its variants. By implementing distance learning, it is hoped that students will listen to material explanations from the teacher and actively participate in learning activities in the form of finding sources of information from other media.

This study aims to determine the effect of distance learning and the role of parents on PAI learning achievement for class VIII SMP Negeri Mojogedang Karanganyar Regency for academic year 2020/2021. The bypothesis proposed is that distance learning and the role of parents have a significant effect on P AI learning achievement for class VIII SMP Negeri Mojogedang Karanganyar Regency for academic year 2020/2021.

This type of research is quantitative descriptive with data collection methods through questionnaires, observations, interviews, and documentation. The research subjects were eighth-grade students of SMP Negeri 2 Mojogedang with a population of 260, and a sample of 116 students was taken.

The results of the study show that: distance learning has a positive and significant effect on PAI learning achievement for class VIII students of SMP Negeri 2 Mojogedang Karanganyar for academic year 2020/2021; the role of parents has a positive and significant impact on P AI learning achievement for grade VIII students of SMP Negeri 2 Mojogedang, Karanganyar Regency for academic year 2020/2021; distance learning and the role of parents have a positive and significant effect on PAI learning achievement for class VIII students of SMP Negeri 2 Mojogedang, Karanganyar Regency for academic year 2020/2021.
\end{abstract}

Keywords: distance learning, the role of parents, learning achievement $P A I$

\title{
A. PENDAHULUAN
}

Akibat globalisasi ini, Munir menyebutkan bahwa dunia pendidikan pada masa kini dan masa yang akan datang ada beberapa kecenderungan antara lain:

1. Pembelajaran jarak jauh (distance learning) yang semakin berkembang dengan adanya kemudahan untuk menyelenggarakan pendidikan terbuka (open education) dan pendidikan jarak jauh (distance education).

2. Sharing resource bersama antar lembaga pendidikan dalam sebuah jaringan.

3. Banyaknya sumber informasi, bukan hanya perpustakaan, melainkan juga instrumen pendidikan lainnya seperti pengajar atau laboratorium, perpustakaan digital melalui internet.

4. Efektifitas pemanfaatan perangkat teknologi informasi dan komunikasi interaktif dengan multimedia, seperti komputer dengan internetnya untuk melengkapi media pembelajaran yang telah ada, sehingga penggunaan media pembelajaran menjadi lebih bervariasi. Variasi media pembelajaran 


\section{Fahima: Jurnal Pendidikan dan Kajian Keislaman}

E E-ISSN: 2808-4349 | P-ISSN: 2808-747X | Volume 1 No. 1 Januari 2022

diperlukan karena tidak ada media yang paling baik atau paling buruk, karena setiap media pembelajaran memiliki kelebihan dan kekurangannya, sehingga kelebihan satu media pembelajaran dapat melengkapi kelemahan media lainnya (Munir, 2009).

Pendidikan Jarak Jauh merupakan suatu keniscayaan di era 4.0. Pendidikan tidak lagi mengandalkan guru sebagai sumber informasi, melainkan dapat mencari sumber informasi lain melalui digital internet. Berbagai variasi, hingga aplikasi yang mendukung pendidikan Pembelajaran Jarak Jauh juga semakin beragam. Dengan adanya kelebihan teknologi saat ini, semua tinggal dikembalikan pada pribadi guru yang mau berkembang dan mengembangkan diri dengan perubahan zaman, pribadi siswa yang bertanggung jawab dalam memperluas wawasan, serta pribadi orang tua yang siap membimbing anaknya di rumah.

Kebutuhan kolaborasi seperti ini sangat dibutuhkan, mengingat siswa Pembelajaran Jarak Jauh membutuhkan peran, serta motivasi orang tua. Serta adanya komunikasi antar orang tua dengan guru mengenai kendala, kesulitan yang dialami siswa selama melaksanakan kegiatan Pembelajaran Jarak Jauh di rumah.

Menghindari sikap impulsif anak dalam menggunakan gadget yang kini menjadi kebutuhan sehari-hari untuk membantu pendidikannya, maka orang tua yang di rumah berhak berperan andil dalam memberikan bimbingan, motivasi, arahan, pengawasan pada anak. Lebih dari itu, orang tua juga seharusnya membangun komunikasi aktif dengan guru, baik mengenai pembelajaran, tantangan, kendala maupun hambatan, agar hasil dari pendidikan ini selaras dengan tujuan pendidikan nasional.

Orang tua atau wali murid memiliki peran besar dalam membantu siswa berhasil dalam pembelajaran jarak jauh. Orang tua bukan guru terlatih dan diminta untuk mengambil tugas yang menantang, sementara mereka juga berurusan dengan tugas dan tuntutan lain di rumah. Mereka akan membutuhkan banyak bimbingan dan dorongan dari guru (Munir, 2009).

Kemendikbud dalam lamannya menyebutkan bahwa Pembelajaran Jarak Jauh bertujuan untuk mendorong kolaborasi orangtua, guru dan murid untuk berdaya belajar dalam menghadapi situasi darurat akibat wabah Covid19 (Dirjen GTK Kemdikbud, 2020). Hal ini berarti kegiatan PJJ turut mengaktif sertakan orang tua, murid dan guru agar dapat saling bersinergi dalam kegiatan belajar terutama dalam menghadapi situasi pandemi seperti saat ini.

Keberhasilan sebuah pendidikan tidak sekedar dilihat dari keberhasilan seorang pendidik menanamkan kemampuan intelektual yang 
mumpuni kepada peserta didik, namun juga diharapkan melalui adanya proses pendidikan dapat mencetak peserta didik memiliki karakter yang baik sebagaimana tertuang dalam undang - undang. Disebutkan bahwa UndangUndang Sistem Pendidikan Nasional mengamanatkan, tujuan pendidikan adalah menjadikan peserta didik sebagai manusia beriman dan bertakwa, berakhlak mulia, sehat lahir maupun bathin, berilmu, memiliki kecakapan dan kreatifitas, memiliki kemandirian, menjadi warga negara yang demokratis dan memiliki sikap yang bertanggung jawab (Mastuhu, 1994).

Kemampuan intelektual yang mumpuni bukanlah tujuan dari UU pendidikan nasional, melainkan keberhasilan pendidikan juga berkaitan dengan spiritual yang terbentuk dalam diri anak ketika proses pendidikan berlangsung. sehingga di masa mendatang, para peserta didik dapat yang merupakan penerus bangsa tidak selamanya mengedepankan intelektual, melinkan menyertakan agama dalam sendi kehidupan.

Dalam rangka mewujudkan hal tersebut, pemerintah telah merancang sistem pendidikan nasional yang menitik beratkan output dan outcome-nya pada tiga aspek utama, yaitu: aspek pengetahuan (knowledge), keterampilan (skill) dan sikap (attitude). Dengan pola ini diharapkan seorang peserta didik (murid/siswa) nantinya memiliki kualitas SDM yang siap melakukan perubahan yang lebih baik negeri ini di masa yang akan datang.

Rancangan pemerintah dalam sistem pendidikan nasional dapat diberatkan pada aspek pengetahuan, keterampilan maupun sikap. Dengan ketiga aspek tersebut, diharapkan peserta didik dalam berpengetahuan, maupun berketerampilan tetap mengedepankan norma-norma yang berlaku dalam masyarakat maupun agama.

Pembelajaran Tatap Muka (PTM) merupakan harapan banyak pihak. Terutama bagi orang tua yang sejauh ini banyak menyerahkan bantuan pendidikan untuk anak pada sekolah. Sehingga ketika pandemi datang, peranan guru di sekolah banyak berpindah pada orang tua, terutama karena kondisi pembelajaran yang dilakukan di rumah. Peranan membimbing, mengarahkan, dan memotivasi anak agar tujuan pendidikan tercapai ini juga dibebankan pada orang tua dengan berkolaborasi bersama guru. Sehingga peranan orang tua dalam hal ini tidak bisa digantikan oleh kecanggihan teknologi, seperti internet, komputer, radio dan media pembelajaran lainnya. Karena anak usia sekolah adalah individu yang memerlukan bimbingan dalam belajar.

Pola asuh dari orang tua bisa menentukan cara bertindak, berpikir dan bersikap. Menjadi orang yang berguna seperti kata Rasulullah SAW: orang yang baik adalah orang yang bermanfaat bagi orang lain.Salah satu tujuan dari pola pengasuhan anak oleh orang tua adalah untuk membuat anak menjadi 


\section{Fahima: Jurnal Pendidikan dan Kajian Keislaman}

E E-ISSN: 2808-4349 | P-ISSN: 2808-747X | Volume 1 No. 1 Januari 2022

orang yang bermanfaat bagi orang lain. Perbedaan sikap orang tua terhadap anaknya bisa membentuk kepribadian yang berbeda pula. Keberhasilan pembentukan karakter pada anak ini salah satunya dipengaruhi oleh pola asuh orang tua. Pola asuh orang tua terbagi menjadi tiga macam yaitu demokratif, permisif, dan otoritatif. Masing-masing pola asuh ini mempunyai dampak bagi perkembangan anak (Latipah, 2012).

Pendidikan sikap dan karakter merupakan pendidikan yang mungkin terasa sulit untuk dijangkau oleh guru aupun lembaga sekolahan untuk pendidikan dengan metode pembelajaran jarak jauh kini. Namun dengan adanya pola asuh orang tua yang baik, diharapkan pendidikan karakter dapat terimplementasi dalam diri anak.

Trianto dalam Hidayat menyatakan bahwa belajar adalah suatu proses atau aktivitas untuk memproses memperoleh pengetahuan, meningkatkan ketrampilan, memperbaiki perilaku dan sikap, serta mengukuhkan kepribadian (Hidayat, 2019). Burton dalam Aunurrahman menyatakan bahwa belajar adalah perubahan tingkah laku pada diri individu berkat adanya interaksi antara individu dengan individu dan individu dengan lingkungannya sehingga mereka mampu berinteraksi dengan lingkungannya (Aunurrahman, 2011).

Mulyono Abdurrahman, menyatakan bahwa prestasi belajar adalah kemampuan yang diperoleh anak setelah melalui kegiatan belajar (Abdurrahman, 2003). Seseorang dikatakan telah belajar dapat dicirikan dengan perubahan yang terjadi akibat belajar. Perubahan ini terjadi secara sadar, bersifat continue, positif dan aktif, permanen, mempunyai arah dan mencakup seluruh aspek tingkah laku (Aunurrahman, 2011).

Sebabnya, mata pelajaran PAI diharapkan dapat mendidik dan menanamkan karakter yang baik pada siswa sebagai seorang hamba. Karenanya dalam persoalan pendidikan agama, maka pendidikan agama harus dilakukan secara utuh, tidak secara parsial, atau terputus-putus. Ketika pendidikan agama dilakukan secara parsial, maka akan menghasilkan pengetahuan yang parsial, dan kemudian berdampak pada perilaku peyimpangan.

\section{B. METODE PENELITIAN}

Jenis pendekatan dalam penelitian ini adalah studi lapangan (deskriptif kuantitatif). penelitian deskriptif kuantitatif untuk mengetahui gambaran pengaruh pembelajaran jarak jauh dan peran orang tua terhadap prestasi belajar PAI siswa kelas VIII SMP Negeri 2 Mojogedang Kabupaten Karanganyar. Metode pengambilan data menggunakan angket, wawancara dan observasi. Populasi penelitian adalah 260 siswa dan diambil sampel sebanyak 
5\%, yaitu 116 siswa kelas VIII.

Tempat penelitian adalah SMP Negeri 2 Mojogedang Kabupaten Karanganyar.

\section{HASIL DAN PEMBAHASAN}

\section{Pembelajaran Jarak Jauh, Peran Oran Tua dan Prestasi Belajar}

Menurut Dewi, pembelajaran daring merupakan pemanfaatan jaringan internet dalam proses pembelajaran. Dengan pembelajaran daring, siswa memiliki keleluasaan waktu belajar, dapat belajar kapanpun dan dimanapun. Pembelajaran daring dilakukan dengan disesuaikan kemampuan masing-masing sekolah. Pembelajaran daring (online) dapat menggunakan teknologi digital seperti google classroom, rumah belajar, zoom, video conference, telepon atau live chat dan lainnya (Dewi, 2020).

Kegiatan pembelajaran daring memberikan keleluasaan pada siswa untuk mengakses belajar merdeka yang dapat dilakukan di manapun, kapapun tanpa terbatas waktu maupun tempat. Selain itu, model pembelajaran daring dapat memanfaatkan berbagai aplikasi yang dapat menunjang saran belajar di dalamnya. Saat ini terdapat banyak penyedia layanan aplikasi online yang membantu siswa dalam belajar, termasuk dalam memenuhi kebutuhan keingintahuan mereka, serta menyelesaikan tugas sekolah salah satunya.

Mahnun dalam bukunya menyebutkan bahwa karakteristik dari pembelajaran online yaitu memungkinkan peserta didik belajar tanpa harus pergi ke ruang kelas, dan pembelajaran dapat dijadwalkan sesuai kesepakatan antara instruktur dan peserta didik, atau peserta didik dapat menentukan sendiri waktu belajar yang diinginkan. Sedangkan menurut Ruth Colvin Clark dan Richard E. Mayer yaitu; Pertama Pembelajaran berbasis online harus memiliki dua unsur penting yaitu informasi dan metode pengajaran yang memudahkan orang untuk memahami konten pelajaran. Kedua Pembelajaran berbasis online dilakukan melalui komputer menggunakan tulisan, suara, atau gambar seperti ilustrasi, photo, animasi, dan video. Ketiga Pembelajaran berbasis online diperuntukkan untuk membantu pendidik mengajar seorang peserta didik secara objektif (Mahnun, 2018).

Pembelajaran Jarak Jauh dapat dilakukan melalui perangkat gadget dengan memanfaatkan multimedia maupun aplikasi yang dapat mendukung kegiatan pembelajaran. Dalam situasi ini guru harus dapat menguasai perkembangan teknologi, agar dapat melaksanakan pembelajaran jarak jauh dengan interaktif dan atraktif. 


\section{Fahima: Jurnal Pendidikan dan Kajian Keislaman}

E E-ISSN: 2808-4349 | P-ISSN: 2808-747X | Volume 1 No. 1 Januari 2022

UU. No. 14 tahun 2005 tentang Guru dan Dosen menyebutkan bahwa guru adalah seseorang yang profesional dan memiliki ilmu pengetahuan, serta mengajarkan imunya pada orang lain, sehingga orang tersebut mempunyai peningkatan dalam kualitas sumber daya manusianya (Republik Indonesia, 2005).

Kamus Besar Bahasa Indonesia mengartikan peranan sebagai Tindakan yang dilakukan oleh seseorang dalam suatu peristiwa (Poerwadarmnita, 1995). Artinya ketika orang tua memiliki peran dalam pelaksanaan bimbingan, maka orang tua memiliki Tindakan-tindakan tertentu untuk membimbing anak, agar anak menjadi lebih terarah.

Departemen Pendidikan Nasional berpendapat bahwa peranan adalah perangkat tingkah laku yang diharapkan atau dimiliki oleh orang yang berkecukupan di masyarakat, peran terutama ditentukan oleh ciri-ciri individual yang bersifat khas atau istimewa(Rahmah \& Jonyanis, 2015).

Novrinda dalam Agustin menyebutkan bahwa Orang tua adalah pria dan wanita yang terikat dalam perkawinan dan siap sedia untuk memikul tanggung jawab sebagai ayah dan ibu dari anak-anak yang dilahirkannya.

Pendapat ini menjelaskan bahwa orang tua adalah pria dan wanita yang terikat dalam pernikahan dan siap menjalankan perannya sebagai ayah dan ibu dari anak-anak yang yang dilahirkannya dengan kasih sayang.

Peranan orang tua ini dapat diartikan bahwa ayah dan ibu yang mengemban amanah sebagai orang tua, menjalankan perannya dalam mengasuh, membimbing, mendidik, membesarkan, memberikan kasih sayang dan perhatian pada anaknya.

Heriyani menjelaskan bahwa orang tua ibu dan ayah memegang peranan yang penting dan sangat berpengaruh atas pendidikan anakanaknya. Seorang ayah berperan mengelola dan mengatur seluruh urusan anak serta memberi arah-arahan yang tepat dan berguna. Seorang ayah juga berkewajiban untuk mencari nafkah bagi keluarganya dan juga berkewajiban untuk mencari tambahan ilmu bagi dirinya, karena dengan ilmu-ilmu itu dia akan dapat membimbing dan mendidik dirinya sendiri dan keluarga menjadi lebih baik. Demikian halnya seorang ibu, disamping memiliki kewajiban untuk mencari ilmu karena ibulah yang selalu dekat dengan anak-anaknya (Heriyani, 2010).

Orang tua yang terdiri dari ayah dan ibu memiliki tugas masing-masing untuk menjaga keharmonisan rumah tangga. Ayah dan ibu sama-sama memiliki tugas untuk mencari ilmu, agar kebutuhan fikriyahnya terpenuhi, serta mampu mengikuti perkembangan zaman yang ada. Termasuk dalam memberikan kepengengasuhan, kependidikan pada anak-anaknya sesuai 
dengan keadaan yang ada. Terutama untuk ibu, kebutuhan ilmu sangat penting. Karena ibu merupakan gerbang utama sebuah keutuhan, keharmonisan rumah tangga. Dengan ilmu yang dimilikinya, ibu mampu mendidik, mengasuh dan merawat anak-anaknya dengan baik.

Pembelajaran dengan menggunakan Strategi Information Search dapat meningkatkan prestasi belajar sisawa. Karena strategi Information Search adalah strategi dimana siswa berkelompok mencari informasi untuk menjawab pertanyaan yang diberikan oleh guru. Informasi tersebut bisa diperoleh dari buku, majalah, internet, modul dan sumber belajar lainnya. Strategi ini sangat membantu pembelajaran untuk lebih menarik, dan menjadikan siswa lebih aktif (Rohim, 2015).

Prestasi belajar siswa pada mata pelajaran PAI sampai saat ini belum mencapai hasil yang memuaskan. Berdasarkan hasil ulangan harian menunjukkan masih terdapat nilai yang berada di bawah kriteria ketuntasan minimal (KKM). Hal ini terlihat pada perolehan nilai terendah yang lebih kecil dari nilai KKM. Siswa yang telah mencapai kriteria ketuntasan minimal (KKM) sebesar 67, baru sebanyak 70\%, dan siswa yang belum tuntas belajar sebanyak 30\%.

Berdasarkan pencapaian prestasi belajar tersebut menunjukkan terdapat suatu permasalahan, yakni masih terdapat siswa yang belum tuntas belajar. Penyebab tidak tuntasnya hasil belajar ini berasal dari faktor internal yang berasal dari dalam diri siswa, maupun faktor eksternal yang berasal dari luar diri siswa. Berangkat dari refleksi guru, hal ini karena rendahnya motivasi siswa dalam mengikuti kegiatan pembelajaran dan juga akibat dari strategi yang digunakan oleh guru saat pembelajaran berlangsung.

Keberhasilan pembelajaran akan menjadi efektif bergantung dari berbagai faktor. Salah satunya adalah bagaimana seorang guru dapat mengemas strategi pembelajaran. Strategi belajar mengajar (Saefuddin \& Berdiati, 2016) adalah semua daya upaya dan siasat yang dilakukan oleh guru dalam menciptakan suatu sistem lingkungan yang memungkinkan terjadinya prosese pembelajaran agar tujuan yang telah dirumuskan dapat tercapai dan berhasil guna. Hasil penelitian Jumaeda menunjukkan bahwa motivasi dan strategi pembelajaran guru pada mata pelajaran PAI memiliki hubungan yang cukup erat dimana hubungan itu saling mempengaruhi satu sama lainnya yaitu dimana motivasi dapat mempengaruhi prosesm pembelajaran yang dilakukan, dan begitupun sebaliknya strategi pembelajaran yang diterapkan oleh guru mata pelajaran PAI dapat mempengaruhi motivasi peserta didik. Dimana jika guru menerapkan strategi pembelajaran yang menarik, disesuaikan dengan karakteristik dan 


\section{Fahima: Jurnal Pendidikan dan Kajian Keislaman}

E E-ISSN: 2808-4349 | P-ISSN: 2808-747X | Volume 1 No. 1 Januari 2022

keadaan psikologi peserta didik maka hal itu akan meningkatkan motivasi belajar peserta didik dalam mengikuti pembelajaran PAI yang diberikan oleh guru (Jumaeda, 2014).

\section{Hasil Penelitian}

Hipotesis pertama yang diajukan dalam penelitian ini terbukti bahwa pembelajaran jarak jauh di tengah pandemi Covid-19 berpengaruh signifikan positif terhadap perilaku religius siswa SMP Muhammadiyah 1 Kartasura tahun pelajaran 2020/2021 dengan perolehan nilai $t_{\text {hitung }}>t_{\text {tabel }}$ $(4,610>2,008)$ dan nilai probabilitas $<0,05$.

Pengarub Pembelajaran Jarak Jauh terhadap Prestasi Belajar P AI Siswa Kelas VIII SMP Negeri 2 Mojogedang Kabupaten Karanganyar Tabun Pelajaran 2020/2021

Pengujian hipotesis dengan uji regresi parsial dilaksanakan untuk membuktikan kebenaran dari hipotesis minor yang telah dirumuskan sebelumnya. Hipotesis akan dinyatakan terbukti kebenarannya dan dapat diterima apabila data yang terkumpul dapat mendukung pernyataan hipotesis dan sebaliknya akan di tolak apabila data tidak mendukung. Hasil uji korelasi regresi antara Pembelajaran Jarak Jauh $\left(\mathrm{X}_{1}\right)$ dengan prestasi belajar (Y) yang dilaksanakan dengan bantuan SPSS 18, di paparkan dalam tabel 1.

Tabel 1. Uji Regresi $\mathrm{X}_{1}$ dengan $\mathrm{Y}$

\begin{tabular}{|c|c|c|c|c|}
\hline Variabel & Koefisien $^{\mathrm{a}}$ & Koefisien beta & $\mathrm{T}$ & Sig \\
\hline Kostanta & 5.050 & & -.300 & .764 \\
\hline $\begin{array}{c}\text { Pembelajaran Jarak Jauh } \\
\text { (X1) }\end{array}$ & .719 & .398 & 4.667 & .000 \\
\hline Peran Orang Tua (X2) & .516 & .280 & 3.280 & .001 \\
\hline
\end{tabular}

a. Nilai konstanta (a) bertanda positif (5.050) hal ini menunjukkan adanya pengaruh positif dan searah antara variabel Pembelajaran Jarak Jauh (X1) dan variabel Peran Orang Tua (X2) terhadap variabel Prestasi Belajar PAI (Y).

b. Nilai koefisien regresi variabel Pembelajaran Jarak Jauh $\left(\mathrm{b}_{2}\right)$ yang bertanda positif (0.719) menunjukkan adanya pengaruh yang positif terhadap Peran Orang Tua (Y) terhadap variabel Prestasi Belajar PAI (Y). Artinya jika variabel Pembelajaran Jarak Jauh (X1) di tingkatkan akan meningkatkan variabel Peran Orang Tua (Y).

Dari hasil regresi linier tersebut di atas maka dapat dijabarkan Variabel 
Pembelajaran Jarak Jauh (X1) pada tabel uji regresi di atas menunjukkan:

a. Nilai konstanta bernilai positif (0.719), menunjukkan adanya pengaruh yang positif dan searah variabel Pembelajaran Jarak Jauh (X1) terhadap variabel Peran Orang Tua (Y). Artinya jika variabel Pembelajaran Jarak Jauh (X1) ditingkatkan akan meningkatkan variabel Peran Orang Tua (Y).

b. Nilai t (4.667) dan sig (.000), nilai t dan sig. pada uji regresi inilah yang di sebut uji t. Uji t ini berguna untuk mengetahui apakah dalam regresi variabel tersebut mempunyai pengaruh atau tidak, pengaruh yang signifikan atau tidak.

Jika nilai sig $<0,05$, maka variabel independent (X1) secara parsial (sendiri) berpengaruh signifikan terhadap variabel dependent $(\mathrm{Y})$. Dari hasil uji t tersebut dapat di simpulkan bahwa t hitung variabel bebas (X1) Pembelajaran Jarak Jauh mempunyai nilai (4.467), lebih besar dari t tabel (0.000) dan nilai sig. variabel bebas (X1) Pembelajaran Jarak Jauh $(0,000)$, lebih kecil dari $(0,05)$. Hal ini berarti variabel bebas (X1) Pembelajaran Jarak Jauh mempunyai pengaruh yang signifikan terhadap variabel terikat (Y) Prestasi Belajar PAI.

Pengaruh Peran Orang Tua terhadap Prestasi Belajar PAI Siswa Kelas VIII SMP Negeri 2 Mojogedang Kabupaten Karanganyar Tabun Pelajaran 2020/2021

Pengujian hipotesis dengan uji regresi parsial dilaksanakan untuk membuktikan kebenaran dari hipotesis minor yang telah dirumuskan sebelumnya. Hipotesis akan dinyatakan terbukti kebenarannya dan dapat diterima apabila data yang terkumpul dapat mendukung pernyataan hipotesis dan sebaliknya akan di tolak apabila data tidak mendukung. Hasil uji korelasi regresi antara Peran Orang Tua $\left(\mathrm{X}_{1}\right)$ dengan prestasi belajar PAI (Y) yang dilaksanakan dengan bantuan SPSS 18, di paparkan dalam tabel 1.

Tabel 1. Uji Regresi $\mathrm{X}_{1}$ dengan $\mathrm{Y}$

\begin{tabular}{|c|c|c|c|c|}
\hline Variabel & Koefisien $^{\mathrm{a}}$ & Koefisien beta & $\mathrm{T}$ & Sig \\
\hline Kostanta & 5.050 & & -.300 & .764 \\
\hline $\begin{array}{c}\text { Pembelajaran Jarak Jauh } \\
(\mathrm{X} 1)\end{array}$ & .719 & .398 & 4.667 & .000 \\
\hline Peran Orang Tua (X2) & .516 & .280 & 3.280 & .001 \\
\hline
\end{tabular}

Berdasarkan persaman regresi linear berganda dalam tabel di atas dapat diketahui bahwa: 


\section{Fahima: Jurnal Pendidikan dan Kajian Keislaman}

E E-ISSN: 2808-4349 | P-ISSN: 2808-747X | Volume 1 No. 1 Januari 2022

a. Nilai konstanta (a) bertanda positif (5.050) hal ini menunjukkan adanya pengaruh positif dan searah antara variabel Pembelajaran Jarak Jauh (X1) dan variabel Peran Orang Tua (X2) terhadap variabel Sikap Belajar Tafsir (Y).

b. Nilai koefisien regresi variabel Pembelajaran Jarak Jauh $\left(\mathrm{b}_{2}\right)$ yang bertanda positif (0.719) menunjukkan adanya pengaruh yang positif terhadap Peran Orang Tua $(\mathrm{Y})$ terhadap variabel Prestasi Belajar PAI (Y). Artinya jika variabel Pembelajaran Jarak Jauh (X1) di tingkatkan akan meningkatkan variabel Peran Orang Tua (Y).

Beradasarkan Variabel Peran Orang Tua (X2) pada tabel uji regresi di atas menunjukkan bahwa:

a. Nilai konstanta bernilai positif (0.516), menunjukkan adanya pengaruh yang positif dan searah variabel Peran Orang Tua (X2) terhadap variabel Pembelajaran Jarak Jauh (Y). Artinya jika variabel Peran Orang Tua (X2) ditingkatkan akan meningkatkan variabel Prestasi Belajar PAI (Y).

b. Nilai t (3.280) dan sig (0.001), nilai t dan sig. pada uji regresi inilah yang disebut uji t., uji $\mathrm{t}$ ini berguna untuk mengetahui apakah dalam regresi variabel tersebut mempunyai pengaruh atau tidak, pengaruh yang signifikan atau tidak.

Jika nilai sig $<0,05$ maka, maka variabel independent $(X)$ secara parsial (sendiri) berpengaruh signifikan terhadap variabel dependent $(\mathrm{Y})$. Dari hasil uji t tersebut dapat disimpulkan bahwa t hitung variabel bebas (X2) Peran Orang Tua mempunyai nilai (3.280), lebih besar dari t tabel (0.0002) dan nilai sig. variabel bebas (X2) Peran Orang Tua mempunyai nilai (0.001), lebih kecil dari $(0,05)$. Hal ini berarti variabel bebas (X2) Pemebelajaran Jarak Jauh mempunyai pengaruh yang signifikan terhadap variabel terikat $(\mathrm{Y})$ Prestasi Belajar PAI.

Pengaruh Pembelajaran Jarak Jauh dan Peran Orang Tua terhadap Prestasi Belajar PAI Siswa Kelas VIII SMP Negeri 2 Mojogedang Kabupaten Karanganyar Tabun Pelajaran 2020/2021

Hasil output uji regresi linier berganda terdapat nilai anova atau uji F, Uji $F$ ini digunakan untuk mengetahui pengaruh dari 2 (dua) variabel independent atau lebih secara simultan (bersama) terhadap variabel dependent. Dasar pengambilan keputusan pada uji $\mathrm{F}$ ini adalah:

a. Berdasarkan nilai $\mathrm{F}$ hitung dan $\mathrm{F}$ tabel

Jika F hitung > F tabel, maka variabel independent (X1 dan X2) secara 
simultan (bersama) berpengaruh terhadap variabel dependent $(\mathrm{Y})$. Rumus $\mathrm{F}$ tabel $=(\mathrm{k} ; \mathrm{n}-\mathrm{k}),(2 ; 114-2),(2 ; 112)$, maka didapatkan hasil dari $\mathrm{F}$ tabel 0.017

b. Berdasarkan nilai signifikansi hasil dari output SPSS

Jika nilai sig $<0,05$, maka variabel independent (X1 dan X2) secara simultan (bersama) berpengaruh terhadap variabel dependent $(\mathrm{Y})$.

Tabel 3. Hasil Uji F

\begin{tabular}{|c|c|c|c|}
\hline Model & F & Sig. & Keterangan \\
\hline Regression & 14.484 & $.000^{\mathrm{a}}$ & Berpengaruh \\
\hline
\end{tabular}

Sumber: Data diolah dengan SPSS

Dari tabel diatas dapat di simpulkan bahwa F hitung (14.484) $>$ F tabel $(0,017)$ dan nilai sig $(0,000<0,05)$ maka variabel independent $(X 1$ dan $X 2)$ secara simultan (bersama) berpengaruh terhadap variabel dependent $(\mathrm{Y})$.

Tahap selanjutnya adalah Interprestasi Koefesien Determinasi ( $R$ Square). Presentase sumbangan pengaruh variabel bebas secara serentak terhadap variabel terikat diketahui dengan metode uji R2 berkisar antara 0 sampai 1. apabila nilai $\mathrm{R} 2=0$ maka tidak ada sedikitpun presentase sumbangan pengaruh dari variabel bebas (X1 dan X2) terhadap variabel terikat $(\mathrm{Y})$ apabila nilai $\mathrm{R} 2=1$ maka sumbangan pengaruh variabel bebas terhadap variabel terikat adalah sempurna. Berdasarkan hasil R2 (tabel summary b) didapat hasil sebagai berikut:

Tabel 4. Hasil Uji R-Square

\begin{tabular}{|c|c|c|c|c|}
\hline Model & $\mathrm{R}$ & $\mathrm{R}$ Square & Adjusted R Square & $\begin{array}{c}\text { Std.Error of } \\
\text { the estimate }\end{array}$ \\
\hline 1 & $.455^{\mathrm{a}}$ & .207 & .193 & 3.831 \\
\hline
\end{tabular}

Sumber: Data diolah dengan SPSS.

Berdasarkan tabel tersebut nilai $\mathrm{R}^{2}$ sebesar 0.455 hal ini menunjukkan bahwa sumbangan pengaruh variabel bebas variabel bebas (X1 dan X2) secara serentak atau bersama-sama terhadap variabel terikat $(\mathrm{Y})$ sebesar 0.207 atau 38\%, sedangkan sisanya yaitu $62 \%$ dipengaruhi faktor lain di luar penelitian ini.

Tahapan selanjutnya yaitu dengan melihat sumbangan efektif (SE) total dan sumbangan relative total (SR) total. Rumus yang digunakan adalah: 


\begin{tabular}{|c|}
\hline SE TOTAL $=$ SE \\
$(\mathbf{X} 1) \%+$ SE $(\mathrm{X} 2) \%$ \\
\hline SR TOTAL $=$ SR $(X 1) \%+S R$ \\
$(X 2) \%$ \\
\hline
\end{tabular}

SE total $=0.2489 \%+0.127 \%$

$=0.3759$ atau 0.376

Dari hasil SE total sama dengan nilai $\mathrm{R}_{2}$ yaitu 0.207

SR total $=0.66 \%+0,34 \%$

$=100 \%$

Kesimpulan:

1. Berdasarkan uji $f$, variabel $X 1$ dan $X 2$ secara bersama-sama mempunyai pengaruh terhadap variabel $\mathrm{Y}$.

2. Berdasarkan uji R2, variabel X1 dan X2 secara bersama sama mempunyai pengaruh sebesar $0.376 \%$ atau $0.38 \%$.

Berdasarkan SE total dan SR total didapatkan hasil $0.376 \%$, sesuai dengan hasil R2 yaitu $0.376 \%$ sedangkan SR total $100 \%$ atau 1.

\section{KESIMPULAN}

Penelitian ini bertujuan untuk menguji pengaruh pengaruh pembelajaran jarak jauh dan peran orang tua terhadap prestasi belajar PAI siswa kelas VIII SMP Negeri Mojogedang Kabupaten Karanganyar Tahun Pelajaran 2020/2021. Berdasarkan analisis, maka pembahasan tentang hasil penelitian adalah sebagai berikut:

1. Pengaruh Pembelajaran Jarak Jauh Terhadap Prestasi Belajar PAI Siswa Kelas VIII SMP Negeri 2 Mojogedang Kabupaten Karanganyar Tahun Pembelajaran 2020/2021 adalah hal ini terbukti positif dan signifikan. Pelaksanaan pembelajaran Jarak Jauh pada mata pelajaran PAI, jika dilaksanakan sebagaimana mestinya, baik dari sisi guru, siswa maupun orang tua, maka akan menghasilkan prestasi belajar yang positif.

2. Pengaruh Peran Orang Tua Terhadap Prestasi Belajar PAI Siswa Kelas VIII SMP Negeri 2 Mojogedang Kabupaten Karanganyar Tahun Pembelajaran 2020/2021 adalah hal ini terbukti positif dan signifikan adalah terdapat pengaruh yang positif dan signifikan. Hal ini berkaitan jika orang tua melaksanakan peranan berupa hak dan kewajibannya, maka 
pembelajaran jarak jauh dapat berjalan dengan baik, serta akan mempengaruhi prestasi belajar PAI siswa.

3. Pengaruh Pembelajaran Jarak Jauh dan Peran Orang Tua Terhadap Prestasi Belajar PAI Siswa Kelas VIII SMP Negeri 2 Mojogedang Kabupaten Karanganyar Tahun Pembelajaran 2020/2021 adalah hal ini terbukti positif dan signifikan.

\section{E. REFERENSI}

Abdurrahman, M. (2003). Pendidikan bagi anak berkesulitan belajar. Rineka Cipta.

Aunurrahman. (2011). Belajar dan Pembelajaran. Alfabheta.

Dewi, W. A. F. (2020). Dampak COVID-19 terhadap Implementasi Pembelajaran Daring di Sekolah Dasar. Edukatif: Jurnal Ilmu Pendidikan, 2(1), 55-61. https://doi.org/10.31004/edukatif.v2i1.89

Dirjen GTK Kemdikbud. (2020). Panduan Pembelajaran Jarah Jaub Bagi Guru selama Sekolah Tutup dan Pandemi Covid-19 dengan semangat Merdeka Belajar. Direktorat Jenderal Guru dan Tenaga dan Tenaga Kependidikan Kementerian Pendidikan dan Kebudayaan.

Heriyani. (2010). Peran Orang Tua dalam Membimbing Belajar Anak. Mata Pelajaran Pendidikan Agama Islam. STAIN Purwokerto.

Hidayat, I. (2019). Strategi Pembelajaran Populer: Kumpulan lengkap teori dan aplikasi pembelajaran masa kini. Diva Press.

Jumaeda, J. (2014). Hubungan Antara Motivasi dan Strategi Pembelajaran Guru pada Mapel PAI di RA Babul Jannah Desa Gunturu Kec. Herlang [Diploma, Universitas Islam Negeri Alauddin Makassar]. http://repositori.uin-alauddin.ac.id/5615/

Latipah, E. (2012). Pengantar Psikologi Pendidikan. Pedagogia.

Mahnun, N. (2018). Implementasi Pembelajaran Online dan Optimalisasi Pengelolaan Pembelajaran berbasis Online di Perguruan Tinggi Islam dalam Mewujudkan World Class University. Indonesian Journal of Islamic Educational Management, 1(1), 8.

Mastuhu. (1994). Dinamika Sistem Pendidikan Pesantren: Suatu Kajian tentang Unsur dan Nilai Sistem Pendidikan Pesantren. INIS.

Munir, M. (2009). Pembelajaran Jarak Jaub Berbasis Teknologi Informasi dan Komunikasi. Alfabeta.

Poerwadarmnita. (1995). Kamus Besar Bahasa Indonesia. Balai Pustaka. 
Fahima: Jurnal Pendidikan dan Kajian Keislaman

E E-ISSN: 2808-4349 | P-ISSN: 2808-747X | Volume 1 No. 1 Januari 2022

Rahmah, A., \& Jonyanis. (2015). Pengaruh Penggunaan Smartphone terhadap Aktivitas Kehidupan Siswa (Studi Kasus MAN 1 Rengat Barat). Jurnal Online Mahasiswa (JOM) Bidang Ilmu Sosial Dan Ilmu Politik, 2(2), 1-12.

Republik Indonesia. (2005). Undang-undang Republik Indonesia Nomor 14 Tabun 2005 tentang Guru dan Dosen. Republik Indonesia.

Rohim, A. Z. (2015). Pengaruh Pennerapann Strategi Information Search terhadap Peningkatan Prestasi Belajar SKI Siswa Kelas VIII MTsN Galur Kulon Progo Yogyakarta [Skripsi, UIN Sunan Kalijaga Yogyakarta]. https://digilib.uin-suka.ac.id/id/eprint/6235/

Saefuddin, A., \& Berdiati, I. (2016). Pembelajaran Efektif. Remaja Rosdakarya. 